\title{
Atypical parasitic lesions in slaughtered cattle in Southern Brazil
}

\section{Lesões parasitárias atípicas em bovinos de abatedouro no Sul do Brasil}

\author{
Welden Panziera ${ }^{*}$ (1); Matheus Viezzer Bianchi1 (1); Andréia Vielmo ${ }^{1}$ (1); Ronaldo Michel Bianchi ${ }^{1}$ (1); \\ Saulo Petinatti Pavarini ${ }^{1}$; ; Luciana Sonne ${ }^{1}$ (1); João Fábio Soares² (1); David Driemeier ${ }^{1}$ (1)
}

\author{
${ }^{1}$ Setor de Patologia Veterinária, Departamento de Patologia Clínica Veterinária, Faculdade de Veterinária, Universidade Federal do \\ Rio Grande do Sul - UFRGS, Porto Alegre, RS, Brasil \\ ${ }^{2}$ Laboratório de Protozoologia e Rickettsioses Vetoriais, Departamento de Patologia Clínica Veterinária, Faculdade de Veterinária - \\ UFRGS, Porto Alegre, RS, Brasil
}

How to cite: Panziera W, Bianchi MV, Vielmo A, Bianchi RM, Pavarini SP, Sonne L, et al. Atypical parasitic lesions in slaughtered cattle in Southern Brazil. Braz J Vet Parasitol 2020; 29(3): e001720. https://doi.org/10.1590/S1984-29612020043

\begin{abstract}
In this study, we described the morphological features and unusual presentations of hydatidosis, fasciolosis, and eosinophilic myositis caused by Sarcocystis species diagnosed at the slaughterhouse lines. Twenty-seven samples of atypical parasitic lesions from distinct cattle were evaluated, of which 12 corresponded to hydatidosis, 11 to fasciolosis, and 4 to eosinophilic sarcocystosis. Hydatid cysts were observed mainly in the heart, with all cases involving the left ventricle. Fasciolosis lesions involved mainly the lungs, and were characterized by a focal nodular elevated area involving the edges of the lobes. Intralesional trematodes were observed in three cases. Sarcocystosis lesions were observed in four cases, and lesions were primarily located in the skeletal and cardiac muscles. Grossly, they presented as focal or focally extensive streaks, patches, or numerous nodules that were greenish to mildly yellowish. Histologically, all the cases had intralesional ruptured cysts of Sarcocystis that were associated with severe eosinophilic myositis and myocarditis. Parasitic lesions in atypical locations and/or with aberrant responses should be promptly identified because it may mistakenly diagnosed as other potentially zoonotic diseases, such as cysticercosis and tuberculosis.
\end{abstract}

Keywords: Cattle diseases, parasitic diseases, hydatidosis, fasciolosis, eosinophilic myositis, zoonosis.

\section{Resumo}

No presente estudo, são descritas as características morfológicas e as apresentações incomuns das lesões parasitárias de hidatidose, fasciolose e miosite eosinofílica por Sarcocystis spp., diagnosticadas nas linhas de abate. Foram analisadas 27 amostras de diferentes bovinos, das quais 12 correspondiam a casos de hidatidose, 11 de fasciolose e 4 de sarcocistose eosinofílica. Os cistos hidáticos foram observados predominantemente no coração, todos com localização no ventrículo esquerdo. As lesões de fasciolose envolveram principalmente os pulmões e eram caracterizadas por áreas nodulares e elevadas nos bordos dos lobos pulmonares. Trematódeos intralesionais estavam presentes em três casos. Lesões de sarcocistose foram observadas em quatro casos, com localização nos músculos esquelético e cardíaco. Macroscopicamente, observaram-se listras, manchas ou numerosos nódulos de coloração esverdeada a discretamente amarelada. Histologicamente, todos os casos apresentaram cistos intralesionais de Sarcocystis spp. rompidos e degenerados, associados à acentuada miosite e miocardite eosinofílica. A identificação das lesões parasitárias em locais poucos frequentes é de extrema importância, pois podem constituir diagnósticos diferencias de enfermidades zoonóticas, como cisticercose e tuberculose.

Palavras-chave: Doenças de bovinos, doenças parasitárias, hidatidose, fasciolose, miosite eosinofílica, zoonose. 
Hydatidosis, fasciolosis, and eosinophilic myositis by Sarcocystis species are parasitic diseases diagnosed at the slaughterhouse lines (Bica et al., 2018; Tessele et al., 2013a, b; Vangeel et al., 2013). These conditions may present as atypical lesions with exacerbate immune responses and/or involving unusual locations. Furthermore, these diseases have distinct viability stages, which makes identification difficult. There are, currently, few studies on parasitic lesions with atypical presentations which also address the morphological features and differential diagnosis of these conditions. Considering the possibility of errors, wrong condemnation criteria, improper destination of carcasses and organs, and the need for a better diagnosis, the aim of this study was to characterize the atypical gross and microscopic features of hydatidosis, fasciolosis, and eosinophilic myositis caused by Sarcocystis species.

A retrospective study of samples of cattle slaughtered in the Rio Grande do Sul state, Brazil, was conducted in search of records from atypical parasitic lesions detected between 2016 and 2019 at the veterinary pathology laboratory. The project that gave rise to the present data was approved by the Research Committee (COMPESQ) of the Universidade Federal do Rio Grande do Sul (UFRGS) (project number 30053). Only organs with macroscopic lesions previously detected by official inspectors, and that generated doubt at the time of slaughter were evaluated. Were included atypical cases of lung and cardiac fasciolosis; heart, spleen, kidney, brain, masseter muscle and ruminal hydatid cysts; and eosinophilic myositis and myocarditis, all caused by Sarcocystis species. The lesions and organs were identified and morphologically evaluated; multiple samples were collected and fixed in $10 \%$ buffered formalin for 24-48h. After fixation, tissues were trimmed, processed for histology, and stained by hematoxylin and eosin technique (HE). Morphological identification of the parasitic agents was performed according to criteria present in previous studies in domestic animals (Gardiner et al., 1998; Gardiner \& Poynton, 1999; Eberhard, 2009).

A total of 27 samples of atypical parasitic lesions from distinct cattle were evaluated, of which 12 corresponded to hydatidosis cases, 11 to fasciolosis, and 4 to eosinophilic myositis caused by Sarcocystis species.

Hydatid cysts were observed in the left ventricle of the heart (5/12), mainly the myocardium (4/5) and pericardium (1/5); spleen (2/12); kidneys (2/12); brain (1/12); skeletal muscle [masseter (1/12)]; and rumen (1/12). The parasitic lesions were characterized by white to yellowish elevated nodular areas that compressed the adjacent tissues (Figures 1A-D). Hydatid cysts were randomly distributed in the organ's parenchyma and varied from 1 to $16 \mathrm{~cm}$ in diameter. On the cut surface, the cysts were classified in two distinct morphological patterns: viable unilocular and degenerate hydatid cysts. The first pattern (6/12) was characterized by a cystic structure filled with a translucent fluid (hydatid liquid) and enveloped by a fibrous capsule. The inner surface of the cyst had a thin membrane, occasionally containing numerous small structures measuring approximately $0.1 \mathrm{~cm}$ in diameter (proliger membranes). The second pattern included the degenerate hydatid cysts (6/12), which on the cut surface showed a parasite with a collapsed and yellowish lamellar membrane tangled inside the cystic cavity.

Microscopically, the viable unilocular hydatid cysts (6/12) were surrounded by a thick external layer of fibrous connective tissue intermixed with an inflammatory infiltrate of lymphocytes, epithelioid macrophages, plasma cells, and eosinophils (host part). The parasite components of the cyst consisted of a laminated hyaline acellular membrane and a thin germinal layer. From this layer, and attached to it by a delicate pediculi, originated the proliger membranes, which contained multiple protoscoleces. These structures presented a tegument and, in some sections, the suckers and part of the rostellum with hooks (Figure 1E). The degenerate hydatid cysts (6/12), on the other hand, had a hypereosinophilic and degenerated laminated membrane, which was tangled within the cystic cavity (Figure 1F) and intermixed with areas of necrosis and mineralization. A severe granulomatous inflammatory infiltrate adjacent to the fibrous capsule or to the laminated membrane was observed, which was composed internally of palisading histiocytes, epithelioid macrophages, and multinucleate giant cells, and externally by lymphocytes, plasma cells, and eosinophils. In one of the cases, the lesion consisted mostly of severe necrosis and mineralization, and the diagnosis was obtained through the identification of fragments of the laminated membrane from the parasite intermixed within the lesion.

Fasciolosis lesions were observed in the lungs (10/11) and right ventricle of the heart (1/11). All these cases concomitantly affected the liver. Grossly, the lung lesions were characterized by a focal nodular and elevated area involving the edges of the lung lobes, measuring from 1 to $10 \mathrm{~cm}$ in diameter. On the cut surface, these nodules contained mostly brownish, friable, caseous material, which was enveloped by a capsule (Figure 2A). In four cases, however, the nodular structures were cystic and had a brownish, viscous fluid. Intralesional trematodes were observed in three out of ten cases of pulmonary fasciolosis, and these had morphological characteristics of $F$. hepatica. The trematodes had a foliaceous flat body, were brownish to greyish, and measured $1.0 \times 0.5 \mathrm{~cm}$. Although the parasites were not observed in the remaining cases (7/10), the morphological aspect of all the lesions was similar. F. hepatica lesion in the heart consisted of a nodular and elevated area affecting the pericardium of 
the right ventricle and measuring $2.0 \mathrm{~cm}$ in diameter. On the cut surface, this nodular heart lesion incorporated a brownish, caseous material surrounded by a fibrous capsule, and contained an intralesional trematode (Figure 2B).

Microscopically, transversal sections of the trematodes were observed in four cases, which were intermixed by marked caseous necrosis (three cases involving the lungs and one involving the heart). The parasites had
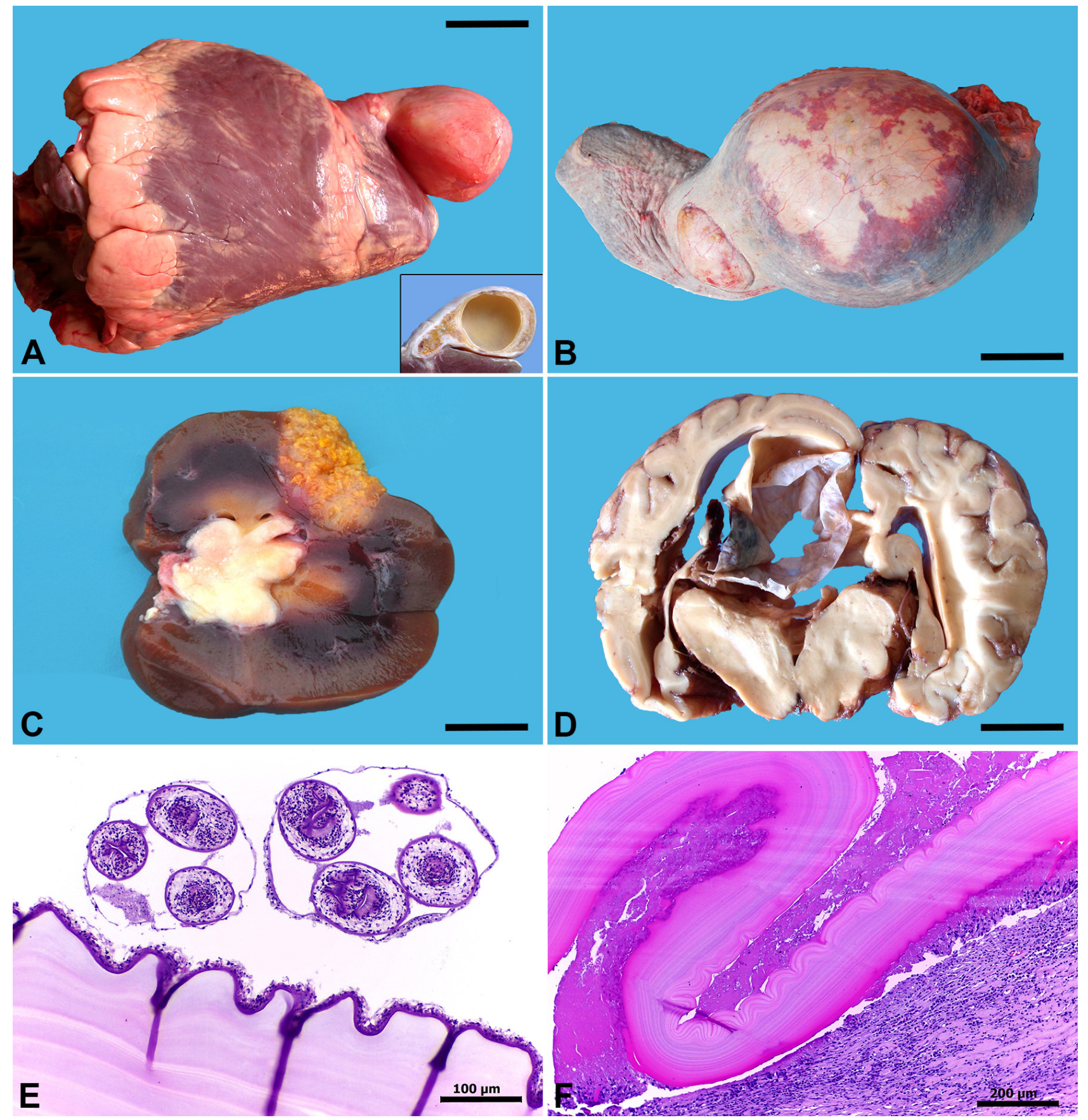

Figure 1. Atypical parasitic lesions in slaughtered cattle. Hydatidosis. (A) Heart. Hydatid cyst involving the left ventricle pericardium. Inset: on the cut surface, the cysts were enveloped by a fibrous capsule and filled with 'hydatid sand'. Bar, $3.4 \mathrm{~cm}$. (B) Spleen. The splenic parenchyma was partially effaced by a large hydatid cyst. Bar, $3.8 \mathrm{~cm}$. (C) Kidney. A degenerate hydatid cyst occupied part of the renal cortex. This cyst was yellowish and did not present a cystic cavity. Bar, $2.4 \mathrm{~cm}$. (D) Brain. The lateral ventricle was distended by a large hydatid cyst that was delineated by a thin fibrous capsule. Adjacent nervous structures (thalamus, hippocampus, and cerebral cortex) were compressed and displaced by the cyst. Bar, $2.7 \mathrm{~cm}$. (E) Microscopical features of a viable hydatid cyst in the heart. The cyst components consisted of an external laminated hyaline acellular membrane and an internal thin germinal layer. Proliger membranes containing multiple protoscoleces originated from this layer. Hematoxylin and eosin (HE). Bar, $100 \mu \mathrm{m}$. (F). Histology of a degenerate hydatid cyst. The laminated membrane was tangled and formed multiple layers in the lumen of the cystic cavity. A severe granulomatous inflammatory infiltrate was observed at the periphery. HE. Bar, $200 \mu \mathrm{m}$. 
an eosinophilic external tegument, which contained spines and an oral sucker on the anterior end. The sucker was characterized by round structures of muscles and fibers disposed radially. The parenchyma of the parasite contained a digestive tract, which was composed of a large intestine (caecum) with the lumen filled, occasionally, by a brown to black pigment. These parasites were compatible morphologically with larval forms of $F$. hepatica due to the absence of reproductive organs (Figure 2C). Pulmonary and cardiac fasciolosis lesions were characterized by severe caseous necrosis, with large amounts of cellular debris surrounded by an intense inflammatory infiltrate of eosinophils (Figure 2D). There were also mild amounts of macrophages, lymphocytes, and plasma cells adjacent to areas with inflammatory infiltrate containing palisading histiocytes and occasional multinucleate giant cells. At the periphery of these lesions, there was marked fibrous connective tissue proliferation. Other abnormalities observed in the lungs included severe bronchiectasis adjacent to the lesion, including occlusion of the bronchi and bronchioli lumen by necrotic debris, as well as epithelium hyperplasia.

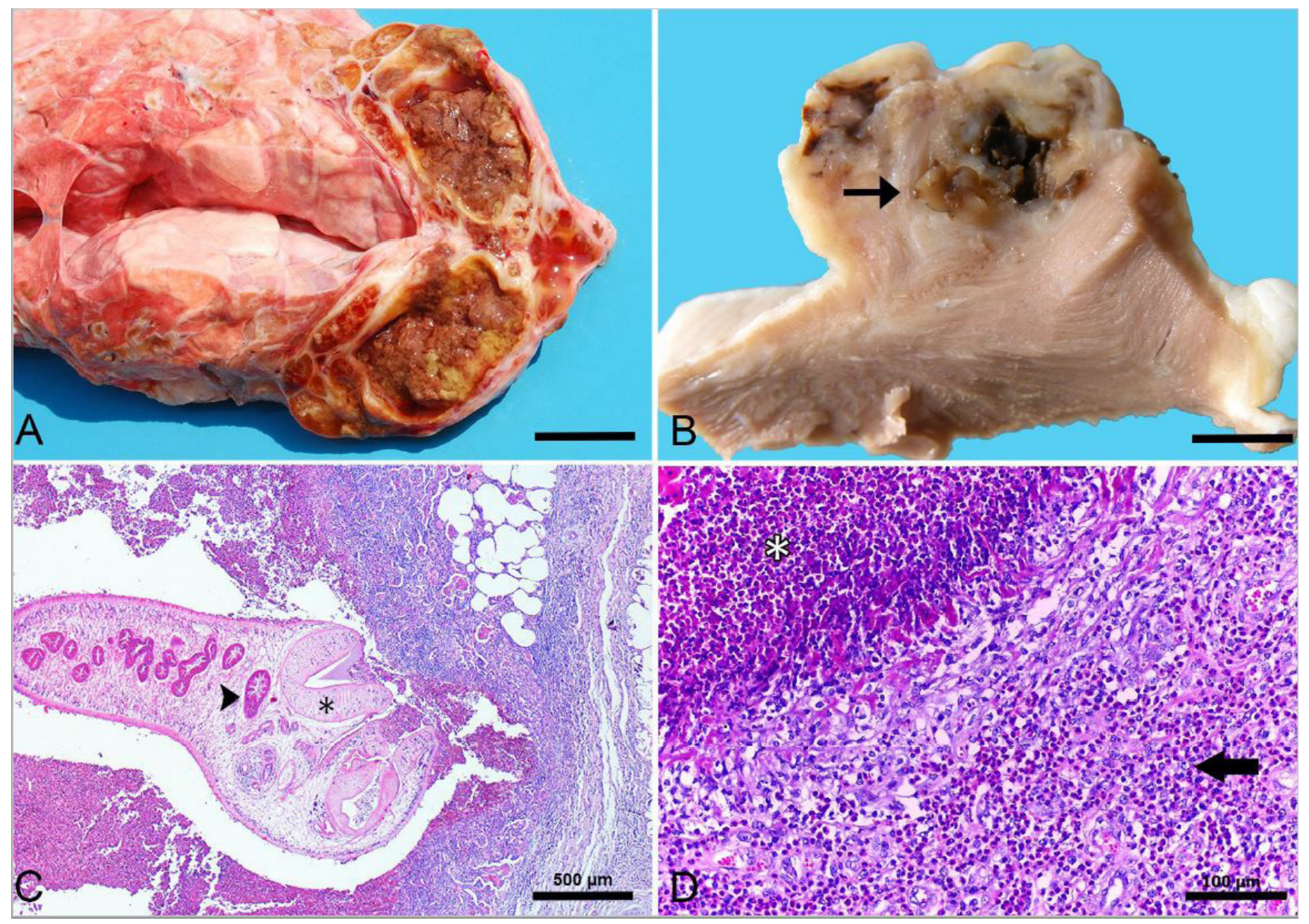

Figure 2. Atypical parasitic lesions in slaughtered cattle. Fasciolosis. (A) Lung. The edge of the lung lobe had a cystic nodular area, which on the cut surface contained a brownish friable caseous material. Bar, $1.7 \mathrm{~cm}$. (B) Heart. Cut surface of the fixed tissue affected by erratic fasciolosis showed a nodular and elevated area involving the pericardium of the right ventricle. The lumen of this nodular area had an intralesional trematode (arrow). Bar, $0.7 \mathrm{~cm}$. (C) Lungs. Histological features of lung fasciolosis. The parenchyma had severe caseous necrosis intermixed by a transverse section of a larval form of Fasciola hepatica. The trematode was covered by an eosinophilic external tegument and possessed an oral sucker on the anterior end (asterisk), as well as a large intestine (caecum) in the lumen (arrow head). Hematoxylin and eosin (HE). Bar, $500 \mu$ m. (D) Lungs. Caseous necrosis areas (asterisk) were surrounded by a severe inflammatory infiltrate composed mainly of eosinophils (arrow). HE. Bar, $100 \mu \mathrm{m}$.

Sarcocystis species-associated lesions were observed in four cases of the present study, and lesions were primarily located in the masseter skeletal muscle (1/4), pectoral skeletal muscle (1/4), and the heart (1/4); the remaining case concomitantly affected the heart, masseter muscle, and tongue. Grossly, it presented as focal or focally extensive streaks, patches, or numerous nodules $(0.1$ to $0.5 \mathrm{~cm}$ in diameter) that were greenish to mildly yellowish and involved the skeletal muscle and myocardium (Figures 3A-3B). Histologically, all the cases had intralesional cysts 


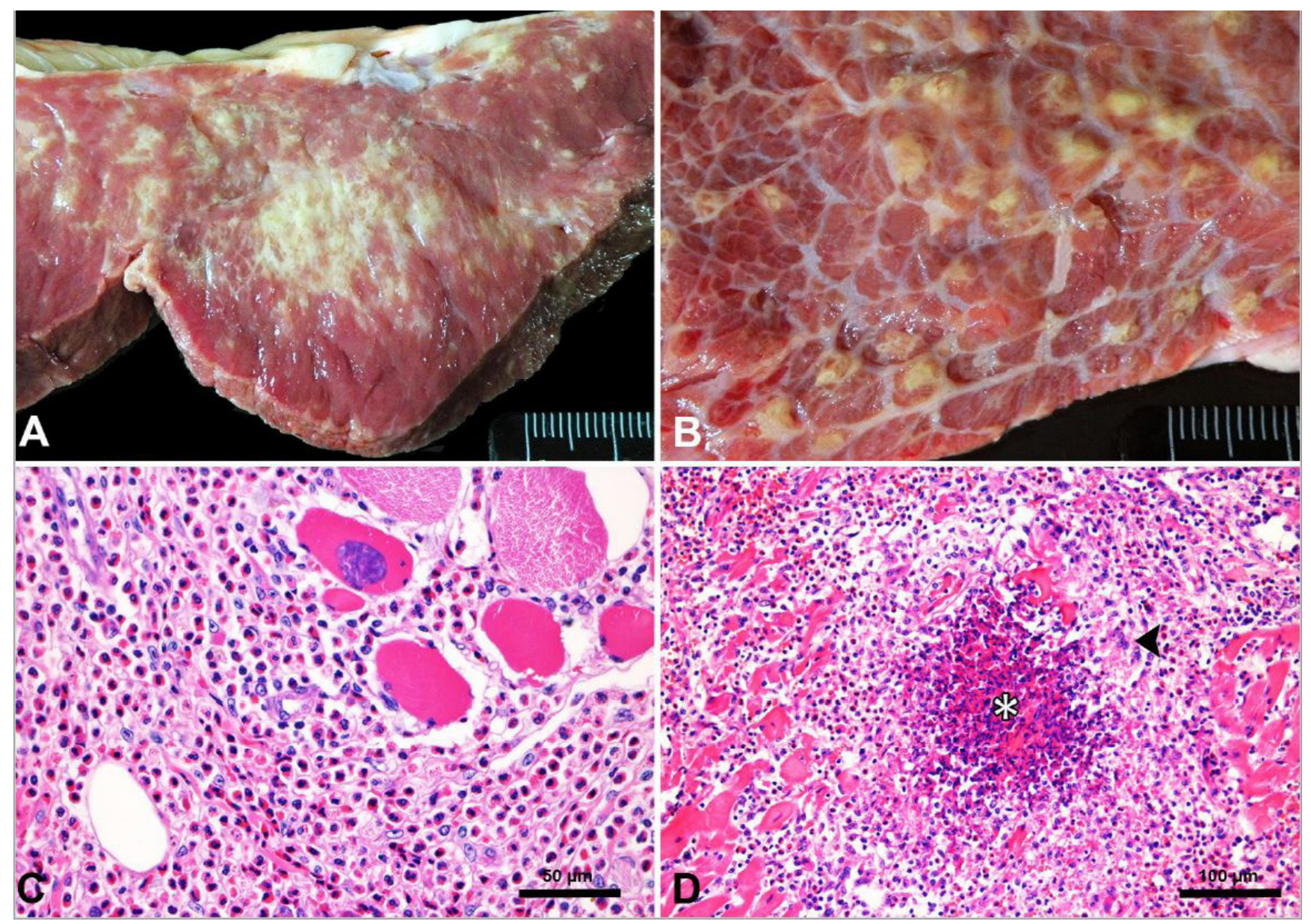

Figure 3. Atypical parasitic lesions in slaughtered cattle. Eosinophilic myositis by Sarcocystis species. (A). Heart. Multifocal to coalescent, greenish to yellowish patchy areas. Bar, $1.5 \mathrm{~cm}$. (B) Skeletal muscle. Random greenish to yellowish irregular nodular lesions. Bar, $1.1 \mathrm{~cm}$. (C) Histological lesion of sarcocystosis involving the skeletal muscle. There was a severe eosinophilic inflammatory infiltrate disrupting the muscle fibers. At the periphery of the lesions, intact cysts were observed in the sarcoplasm of the myofibers. Hematoxylin and eosin (HE). Bar, $50 \mu \mathrm{m}$. (D) Heart. In a few areas, the lesions presented a necrotic center (asterisk) containing degenerated eosinophils and occasional debris of necrotic fibers which was surrounded by an inflammatory infiltrate of palisading histiocytes, epithelioid macrophages, and occasional multinucleate giant cells (arrow head). HE. Bar, $100 \mu \mathrm{m}$.

of Sarcocystis species, frequently ruptured and degenerated, associated with areas of severe eosinophilic myositis and myocarditis, which dissected the myofibers (Figure 3C). In a few areas, the lesions presented a necrotic center containing degenerated eosinophils and occasional debris of necrotic fibers (Figure 3D), which was surrounded by a severe inflammatory infiltrate of palisading histiocytes, epithelioid macrophages, and occasional multinucleate giant cells. In the areas adjacent to the lesion, numerous intact cysts without inflammatory response were observed.

The diagnosis of fasciolosis, hydatidosis, and eosinophilic myositis caused by Sarcocystis species in this study was based on the gross and microscopic features of each condition. These parasitic diseases are commonly detected in cattle at the slaughterhouse lines in the Rio Grande do Sul state (Bica et al., 2018; Tessele et al., 2013a, b), as well as in other locations, in which hydatidosis stands out (Cardona \& Carmena, 2013). Apart from being a health issue for consumers, these conditions cause economic losses for the cattle industry and producers (Cardona \& Carmena, 2013; Costa et al., 2019). Moreover, hydatidosis is a zoonotic parasitic disease, and it is one of the most common diseases identified in developing countries of African, Asian, and South American continents (Cardona \& Carmena, 2013). Usually, in the intermediate host, the oncospheres are released from the eggs and migrate either through the blood vessels to the liver or through the lymphatics to the lungs. Thus, the lungs and liver are the most common sites affected by metacestode development in cattle and sheep (Panziera et al., 2018; Tessele et al., 2013a). The hydatids cysts observed in the cattle of the present study may be explained by the fact that, occasionally, the oncospheres can escape into the general circulation of the animal (Tessele et al., 2013a; Uzal et al., 2016). Although only lesions that generated doubt at the inspection were considered in this study, and, 
thus, other hydatid cysts in common locations were not evaluated, the heart appeared to be the most commonly organ affected by erratic migrations in cattle, wherein the left ventricle was the most affected site by the cysts. Similar data have been described in humans, in which cardiac involvement is rare and usually affects the left ventricle (Uygur et al., 2017), being a result of myocardial seeding with hexacanth embryos, which can be deposited by means of the coronary circulation (Pasaoglu et al., 1992). This condition should also be differentiated from cysticercosis in cattle, which may be achieved by the gross observation of lesions, since cysticercosis lesions are usually smaller when compared to hydatid cysts, and viable cysticerci constantly present a central scolex (Panziera et al., 2017). The identification of the viable hydatids in this study was simple, since the parasitic structures were preserved. However, degenerate hydatid cysts may be difficult to diagnosis grossly and to differentiate from tuberculosis and squamous cell carcinomas at the slaughter lines. Some gross features observed in this study that helped to differentiate these conditions were the presence of a collapsed lamellar membrane and the yellowish coloration of the cyst (Tessele et al., 2013a). Histologically, these parasitic degenerated lesions were distinguished mainly by the presence of a laminated membrane, in addition to the palisading histiocytes at the periphery. In some reported cases, the laminated membrane constitutes the only histologic lesion available for the diagnosis of this condition (Eberhard, 2009). These aspects were also observed in the degenerated cysts of the present study, where the laminated membrane was the main criteria for the definitive diagnosis of degenerate hydatidosis. The brain involvement observed in the present study has been rarely described in domestic animals (Uzal et al., 2016), and in humans it is related to cardiac embolization (Turgut et al., 1997). Coenurosis was the main differential criteria for diagnosis in this case; however, microscopically, Coenurus cerebralis presents numerous scoleces and do not present a germinal membrane (Eberhard, 2009), which is inconsistent with the present report.

Fasciola spp. infections with erratic locations are uncommon and rarely described in cattle. Nonetheless, when this condition occurs, it is mainly observed in the lungs (Lee et al., 2016; Tessele et al., 2013a). In these cases, larval forms of the parasite may, accidentally, embolize through the caudal vena cava during hepatic migration, thereby reaching the right heart and lungs (Cullen \& Stalker, 2016). This may explain, respectively, the heart and lung locations observed in the present study. The lung lesions were mainly observed close to the edges of the lung lobes, and corresponded to caseous abscesses or cystic structures, both filled with a friable or brownish liquid content. This gross presentation affecting the edges of the lung lobes suggests that the lesion begins as a peripheral bronchiectasis that later becomes engulfed (Cullen \& Stalker, 2016). The trematodes are scarcely observed when erratic migration occurs (Cullen \& Stalker, 2016; Tessele et al., 2013a), and this explains the fact that parasites were not observed in seven cases. In these cases, the brownish content of the lesion and the gross peripheral location associated with the microscopic features of extensive areas of necrosis, in addition to the severe granulomatous and eosinophilic inflammatory infiltrate, were characteristic of an atypical fasciolosis (Cullen \& Stalker, 2016). In the remaining cases (4/11) in which there was a trematode, the morphological characteristics of the parasite allowed us to classify it as larval forms of $F$. hepatica. These included the gross features of the parasite, such as foliaceous flat body and brownish to greyish color, as well as the microscopical features, such as an eosinophilic tegument covered by spines and an oral sucker on the anterior, in addition to parenchyma containing a digestive tract and absence of reproductive organs, as described for the species (Gardiner \& Poynton, 1999). Cardiac fasciolosis must be differentiated from degenerated cysticercosis. However, the brownish content of the lesion associated with the occasional presence of the trematode may help to differentiate both conditions (Cullen \& Stalker, 2016).

Sarcocystis species, such as S. cruzi, S. hirsuta, and S. hominis, have been suggested to play a role in bovine eosinophilic myositis (Vangeel et al., 2013). Sarcocystis species are frequently observed as an incidental finding on the histologic exam, affecting the muscle fibers with greater blood supply, such as the heart, esophagus, and masseter muscle (Tessele et al., 2013b; Vangeel et al., 2013; Valentine \& McGavin, 2012). Similarly, in the present study, lesions were observed in the skeletal and cardiac muscle. However, the cases described here were classified as atypical due to rupture of the cysts and the inflammatory reaction that surrounded the cysts, which caused the gross lesions. All cases presented ruptured cysts intermixed with the inflammatory reaction (Granstrom et al., 1989; Valentine \& McGavin, 2012), confirming the parasitic etiology of the lesions. Eosinophilic myositis by Sarcocystis species are usually detected at the postmortem exam of cattle, and may be focal or generalized, with concomitantly involvement of skeletal and cardiac muscles, similarly to the observed in the present study. The gross greenish color generally observed is caused by the severe inflammatory infiltrate of eosinophils and characterizes an acute lesion (Cooper \& Valentine, 2016). Heart and skeletal muscles are sites routinely inspected for the diagnosis of cysticercosis (Cysticercus bovis/ cysticercus of Taenia saginata), which facilitates the detection of lesions. Occasionally, degenerate cysticercosis constitutes the main differential diagnosis for this condition, mainly when eosinophilic myositis forms small nodules (Panziera et al., 2017). However, when eosinophilic myositis has this presentation, the nodules are usually multiple and in close proximity, what is not observed in cysticercosis (Cooper \& Valentine, 2016). 
Hydatidosis, fasciolosis, and eosinophilic myositis caused by Sarcocystis species manifested as the atypical parasitic lesions of the present study. The identification of these lesions in atypical locations is extremely important, since these conditions may constitute differential diagnosis of other potentially zoonotic diseases, such as cysticercosis and tuberculosis.

\section{Acknowledgements}

We are grateful to the Conselho Nacional de Desenvolvimento Científico e Tecnológico (CNPq) and Coordenação de Aperfeiçoamento Pessoal de Nível Superior (CAPES) for supporting this study.

\section{References}

Bica RFP, Copetti MV, Brum MCS. Hydatidosis, cysticercosis, and tuberculosis rates in bovine slaughtered under state sanitary inspection in Rio Grande do Sul, Brazil. Cienc Rural 2018; 48(8): 1-7. http://dx.doi.org/10.1590/0103-8478cr20170811.

Cardona GA, Carmena D. A review of the global prevalence, molecular epidemiology and economics of cystic echinococcosis in production animals. Vet Parasitol 2013; 192(1-3): 10-32. http://dx.doi.org/10.1016/j.vetpar.2012.09.027. PMid:23084536.

Cooper BJ, Valentine BA. Muscle and tendon. In: Maxie MG. Jubb, Kennedy, and Palmer's pathology of domestic animals: volume 1. 6th ed. St. Louis: Elsevier; 2016. p. 164-249. http://dx.doi.org/10.1016/B978-0-7020-5317-7.00003-5

Costa RA, Corbellini LG, Castro-Janer E, Riet-Correa F. Evaluation of losses in carcasses of cattle naturally infected with Fasciola hepatica: effects on weight by age range and on carcass quality parameters. Int J Parasitol 2019; 49(11): 867-872. http://dx.doi. org/10.1016/j.ijpara.2019.06.005. PMid:31545963.

Cullen JM, Stalker MJ. Liver and biliary system. In: Maxie MG. Jubb, Kennedy, and Palmer's pathology of domestic animals: volume 2. 6th ed. St. Louis: Elsevier; 2016. p. 258-352. http://dx.doi.org/10.1016/B978-0-7020-5318-4.00008-5

Eberhard ML. Histopathological diagnosis. In: Bowman DD. Georgis' Parasitology for Veterinarians. 9th ed. St. Louis: Saunders Elsevier; 2009. p. 372-406.

Gardiner CH, Fayer R, Dubey JP. An atlas of protozoan parasites in animal tissues. 2nd ed. Washington: Registry of Veterinary Pathology, Armed Forces Institute of Pathology; 1998.

Gardiner CH, Poynton SL. An atlas of metazoan parasites in animal tissues. Washington: Armed Forces Institute of Pathology; 1999.

Granstrom DE, Ridley RK, Baoan Y, Gershwin LJ, Nesbitt PM, Wempe LA. Type-I hypersensitivity as a component of eosinophilic myositis (muscular sarcocystosis) in cattle. Am J Vet Res 1989; 50(4): 571-574. PMid:2496630.

Lee JK, Rosser TG, Cooley J. Pulmonary embolization of immature Fascioloides magna causing fatal hemothorax confirmed by molecular technique in a heifer in the United States. J Vet Diagn Invest 2016; 28(5): 584-588. http://dx.doi. org/10.1177/1040638716660129. PMid:27423736.

Panziera W, Vielmo A, Bianchi RM, Andrade CP, Pavarini SP, Sonne L, et al. Aspectos macroscópicos e histológicos da cisticercose bovina. Pesq Vet Bras 2017; 37(11): 1220-1228. http://dx.doi.org/10.1590/s0100-736×2017001100006.

Panziera W, Vielmo A, De Lorenzo C, Heck LC, Pavarini SP, Sonne L, et al. Characterization of parasitic lesions of sheep observed at slaughter line. Pesq Vet Bras 2018; 38(8): 1491-1504. http://dx.doi.org/10.1590/1678-5150-pvb-5549.

Pasaoglu I, Dogan R, Hazan E, Oram A, Bozer AY. Right ventricular hydatid cyst causing recurrent pulmonary emboli. Eur J Cardiothorac Surg 1992; 6(3): 161-I63. http://dx.doi.org/10.1016/1010-7940(92)90124-G. PMid:1567632.

Tessele B, Brum JS, Barros CSL. Parasitic lesions observed in cattle slaughtered for human consumption. Pesq Vet Bras 2013a; 33(7): 873-889. http://dx.doi.org/10.1590/S0100-736X2013000700008.

Tessele B, Vielmo A, Panziera W, Gomes DC, Barros CSL. Eosinophilic myositis in cattle slaughtered for human consumption. Pesq Vet Bras 2013b; 33(11): 1345-1348. http://dx.doi.org/10.1590/S0100-736X2013001100010.

Turgut M, Benli K, Eryilmaz M. Secondary multiple intracranial hydatid cysts caused by intracerebral embolism of cardiac echinococcosis: an exceptional case of hydatidosis.J Neurosurg 1997; 86(4): 714-718. http://dx.doi.org/10.3171/jns.1997.86.4.0714. PMid:9120638.

Uygur B, Ustabasioglu FE, Karakurt H, Akinci O, Celik O. An unusual cause of chest pain: an isolated huge cardiac hydatid cyst. J Clin Ultrasound 2017; 46(4): 262-264. http://dx.doi.org/10.1002/jcu.22518. PMid:28656619.

Uzal FA, Plattner BL, Hostetter JM. Alimentary system. In: Maxie MG. Jubb, Kennedy, and Palmer's pathology of domestic animals: volume 2. 6th ed. St. Louis: Elsevier; 2016. p. 1-257. http://dx.doi.org/10.1016/B978-0-7020-5318-4.00007-3 
Atypical parasitic lesions in slaughtered cattle

Valentine BA, McGavin MD. Skeletal system. In: Zachary JJ, McGavin MD. Pathologic Basis of Veterinary Disease. 5th ed. St. Louis: Saunders Elsevier; 2012. p. 908.

Vangeel L, Houf K, Geldhof P, De Preter K, Vercruysse J, Ducatelle R, et al. Different Sarcocystis spp. are present in bovine eosinophilic myositis. Vet Parasitol 2013; 197(3-4): 543-548. http://dx.doi.org/10.1016/j.vetpar.2013.06.001. PMid:23870431. 